\title{
5 \\ Entangled Mobilities: Missions, Māori and the Reshaping of Te Ao Hurihuri
}

\author{
Tony Ballantyne
}

The intersections between the forms of mobility that were integral to the functioning of imperial systems and established patterns of Indigenous movement and circulation offer crucial insights into both the power and limits of empire. Empires have historically operated as highly uneven systems of extraction, appropriation and incorporation, which have been geared towards enhancing the resources, wealth, power and status of the empire-building state. Their functioning has been dependent on creating new connections between peoples and territories, drawing them into circuits of transportation, communication and exchange that enable commodities, capital and labour to be moved from place to place. However, the reach of empires was never complete. Even if the connective networks that gave empires shape were expansive and, in the case of the modern British Empire, world spanning, they were not all encompassing. While, in some regions, various agents of empires were able to fashion a host of thick and strong connections, there were gaps within these networks that allowed the persistence of key aspects of Indigenous life ways. In other territories ostensibly under British control, the empire had limited reach in the face of difficult terrain, resistant or insurgent 'native' communities, or because of the relative absence of marketable resources. 
Thus, even as British imperial networks became more extensive as the nineteenth century progressed, 'native spaces' were entangled within the work of empire to varying degrees. Some spaces integral to the lives of Indigenous communities were firmly woven into the fabric of empire and this required profound shifts in the social organisation, material framework and cultural outlook of Indigenous communities; other spaces were only lightly touched by the reach of the various globalising forces that extended the formal power and informal influence of Britain. Voluntary associations created by British evangelicals committed to the project of bringing the Gospel to native communities created a host of such connections, even though evangelicals could, at times, be fierce critics of what they saw as the immorality or excesses of certain forms of colonialism. The British Protestant 'global overlay' created by missionaries - made up of mission stations, schools, hospitals, shipping and transportation networks, print shops and a seemingly ceaseless flow of texts-was a powerfully integrative force that provided a range of novel technologies, ideas and practices that were often reworked by Indigenous and colonised communities at the edge of empire, forming key elements of emergent modern cultural formations. ${ }^{1}$

My recent monograph, Entanglements of Empire, argued that thinking through the metaphor of 'entanglement' allows us to gain greater insights into the operation of empire in the Pacific and the abiding consequences of empire building than thinking of cross-cultural engagements as 'meetings' or 'encounters'. 'Entanglement' stresses both the mutually constitutive nature of these relationships that took shape at the edge of the empire and their transformative power, highlighting how they reshaped cultural formations, often in ways that were unpredictable and unexpected. ${ }^{2}$ To gauge the impact of these entanglements, it is crucial to not only map pre-existing Indigenous cultural patterns, but to be aware of how those dynamics changed prior to (and during) the onset of cross-cultural engagement. ${ }^{3}$

With these aspirations at its heart, this chapter explores some of the entanglements that resulted from the extension of British missionary activity into Māori communities in Te Ika a Māui, New Zealand's

1 The notion of a 'global overlay' comes from Adshead 1997: 244.

2 Ballantyne 2014b: 16-18, 251-52, 257. An important earlier use of 'entanglement' in the Pacific was Thomas 1991. Other key works that have demonstrated the usefulness of 'entanglement' as a heuristic tool are Hamilton 1998: especially 3-4; Nuttall 2009.

3 Ballantyne 2005: 447-49. 
North Island. It particularly focuses on the first decade of the Church Missionary Society (CMS) mission to New Zealand and the ways in which Māori engagement with the mission created new patterns of trade, catalysed new forms of movement and recalibrated and redirected long-established traditions of mobility. The analysis developed here is anchored in Mimi Sheller and John Urry's argument that reconstructing shifting forms and patterns of movement offers crucial insight into the changing shape and meaning of social formations. ${ }^{4}$ New mobile orders were fundamental to the routine operations of missionary work, and mission stations-beginning with Hohi in 1823, then Kerikeri in 1819 and Te Puna and Paihia in 1823-reshaped the ways in which pathways and connections operated in the region. I particularly emphasise the connections between the motion of Indigenous people and the mobility of things, highlighting how novel technologies and media enabled and shaped new forms of travel, innovative ways of thinking about movement and new mechanisms for recording and explaining those experiences. Central to this argument is the notion that the mission immersed Māori in a world of paper-a paper empire-where paper was not only a key cultural material that was integral to the operation of missionary activity, but where it more broadly underpinned and directed the routines of administration, trade and mobility. ${ }^{5}$

The essay begins by briefly exploring some recent historical writing on Indigenous mobility before sketching how missionary activity reordered, at least partially, the ends, experiences and meanings of mobility on the New Zealand frontier. The final section focuses on paper-its importance in the mission and its connections to the kinetic new social formations that took shape in northern New Zealand from the 1810s. Here I suggest that, as a particular type of thing or artefact, paper was crucially important in an emergent new order because, like other types of objects, it could create connections between people. ${ }^{6}$ However, unlike other objects, such as an adze, fishhook or hoe, the creation of connections between people was one of paper's primary functions and, because of its lightness and portability, it was able to do so over long distances.

\section{$\star \star \star$}

4 Sheller and Urry 2006: 213.

5 I have developed my arguments about the connections between paper and empire in an arc of essays: Ballantyne 2011a; Ballantyne 2013; Ballantyne 2014a; Ballantyne 2016.

6 Hahn and Weis 2013. 
Work on mobility is often structured by an assumption that movement has been a defining characteristic of modernity. Such arguments, of course, are themselves grounded by a series of dichotomised understandings that imagine Indigenous or colonised communities as place bound, local and traditional, as opposed to the open, global and dynamic nature of Western societies. ${ }^{7}$ In the last decade or so, several scholars have challenged the old imperial equation of native and Indigenous with 'local' and 'fixed', and the world of European empires with 'global' and 'mobile'; 8 they have suggested that native or Indigenous peoples could and did possess what James Clifford famously dubbed 'traveling cultures'. ${ }^{9}$ In the Pacific, Damon Salesa has written about 'travel-happy Samoa', arguing that long before the European 'discovery' of Samoa in 1722, the people of those islands had created expansive worlds by voyaging, visiting and trading, as well as various exchange relationships. The rise of European empires and the consolidation of successive and competing colonial regimes in the Pacific certainly reshaped and redirected the 'circuitry' of mobility and social relations within the islands; however, Samoans and other Pacific peoples actively bent those pathways to their own purposes while continuing to move in ways that were largely outside or beyond the purview of colonial states. ${ }^{10}$ More recently, Salesa has discussed the entangled histories of Fiji, Tonga, Samoa, Rotuma, Uvea, Futuna, Niuafo'ou and Niuatoputapu prior to the arrival of Europeans through the lens of a 'native sea'-an Indigenous complex of maritime movement and connection. Salesa's arguments are important because they demonstrate the weakness of old colonial assumptions that Pacific peoples were stable and fixedboth in terms of cultural development and physical location-prior to the intrusion of the British into Oceania. The long and deep history of mobility that Salesa draws our attention to shows that mobility predated modernity in the region, and that Europeans did not suddenly 'activate' the island communities. ${ }^{11}$

In a similar vein, I have demonstrated the need to recognise the importance of mobility in shaping the life ways of the Polynesian communities that settled in New Zealand from the thirteenth century. ${ }^{12}$ It was only in

$7 \quad$ Ballantyne and Burton 2009; Salesa 2003; Ballantyne 2014c.

8 For one useful discussion of this within the Pacific, see Jolly 2001.

9 Clifford 1992.

10 Salesa 2003.

11 Salesa 2013a; Salesa 2013b.

12 Especially in Ballantyne 2011b. 
the half century after sustained contact with Europeans following the arrival of Cook's Endeavour in 1769 that these peoples began describing themselves as 'tāngata Māori' or 'Māori': 'the normal people'. Even after this epistemological shift, the life of these communities continued to be structured around smaller functional units, whānau (extended family units) and hapū (sub-tribes or clans). For larger-scale economic activities and war making, hapū could be mobilised into the larger unit of the iwi (tribe).

The histories of hapū and iwi are typically understood as firmly anchored in space, being tied to specific rohe. Rohe are traditionally understood as the domain over which rangatira (hereditary leaders) of the allied kin groups that made up iwi exercised mana (authority). Such a political interpretation can also be complimented by a more geographically inflected reading. Rohe were the domains produced by the routine patterns and pathways of mobility of allied kin groups-groups that travelled regular circuits to source, process and trade food items and other valued resources, who travelled to meeting-up places for rituals and meetings, and who came together in times of conflict to form taua (war parties). These communities were linked not only by genealogical ties, but also shared pathways across the land and water and had strong ties to place, especially attachments to papa kāinga (home villages) and key landmarks such as maunga (mountains) and awa (rivers).

The apparent fixity of these referents is a modern phenomenon. Prior to the incursions of Europeans, mobility was integral to life ways and the territories that communities occupied often shifted significantly over time. As I have already suggested, mobility was at the core of daily life and the seasonal cycle of economic and social routines. Groups of kin would traverse the landscape to visit relatives, to engage in rituals or to gather together for major economic initiatives, such as large-scale harvesting, the bringing of new land into cultivation or construction projects. Movement also had important political dimensions as it was integral to the maintenance of the equilibrium between social collectives; taua muru (plundering parties) enabled kin groups to seek redress when social infractions impugned on their mana or created an intolerable imbalance. Given the manifold significance of motion and movement in the life ways of these groups, it is not surprising that one of the ways in which Māori describe the human world is 'te ao hurihuri': the world of motion, the ever-moving world. Thus, even though the direct connections from Te Ika a Māui to the rest of Oceania had become attenuated and atrophied 
long before Europeans arrived, complex circuits and pathways linked places and peoples, underscoring Sheller and Urry's insistence on the fundamental importance of mobility as an aspect of social organisation in all human societies. ${ }^{13}$ Recent archaeological research has increasingly moved mobility to the centre of reconstructing the peopling of Te Ika a Māui and Te Wai Pounamu (New Zealand's South Island), and to understanding the development of pre-colonial social formations in these islands. ${ }^{14}$

The Endeavour's careful circumnavigation of New Zealand in 1769-70 punctured the isolation of New Zealand from the rest of the Pacific world. However, it was not until the 1790s, when New Zealand's coasts began to effectively function as a frontier for the fledgling colony of New South Wales, that the place of mobility within the practices of kin groups in Te Ika a Māui was significantly reshaped. There has been surprisingly little work on these mobilities that transformed Māori life in the first half of the nineteenth century. There have been some studies of Māori travellers, but this work has largely been concerned with questions of 'experience' and has been driven by a desire to recover and document these life histories. ${ }^{15}$ Rachel Standfield's chapter in this volume works to extend this scholarship beyond recovery of Māori experience to consider how Māori aspirations shaped mobility and early missionary travel in New Zealand. Less work has been undertaken on the reordering of Māori mobilities within the islands of New Zealand, especially in and around the 'musket wars' of the 1820 s and 1830s, which fundamentally recalibrated the distribution of power and the geographies of settlement and kinship connections. This is not to suggest that this period has been neglected; rather, that it has primarily been approached through the lens of war and not the deepseated geographic redistribution of tāngata/tākata whenua (people of the land).

This essay focuses on an even earlier period, exploring some of the mobilities that developed in association with the early years of the CMS mission that was formally established in the Bay of Islands in 1814, some six years after Samuel Marsden first began to formulate a plan for the evangelisation of Māori. Questions of mobility are prominent, albeit in an often analytically implicit way, in some recent work on the early

13 Sheller and Urry 2006.

14 Most notably, Walter, Jacomb and Bowron-Muth 2010.

15 Especially O’Malley 2015. 
development of the mission. Several scholars, including Anne Salmond, Vincent O’Malley, Rachel Standfield, Alice Te Punga Somerville, Alison Jones and Kuni Jenkins, and Fred Cahir and Ian Clark, have drawn our attention to the significance of Māori travellers who played a key role in what James Belich has called the 'Māori discovery of Europe', but which would be better understood as the 'Māori discovery of the non-Polynesian world'. ${ }^{16}$

In many ways, these travels grew out of, and extended, the connections that developed out of Tuki and Huru's Norfolk Island sojourn following their kidnapping in April $1793 .{ }^{17}$ A sequence of Māori men, including Te Pahi, Ruatara, Te Morenga, Māui, Titere and Tuai, travelled widely, and we have an increasing appreciation of their shifting apprehensions of the world. The stories of these pioneering voyages are very important; however, their experiences should not stand for 'Māori mobility' tout court in this period. Long-distance travel to the Australian colonies, Asia and Europe was one force that significantly reshaped the Māori world, but we need a broader apprehension of the importance of various forms of Māori mobility-both those that underwrote long-established traditions of war making and settlement, as well as those novel forms that developed in connection with the establishment of mission stations from 1814 .

$\star \star \star ~$

The CMS mission to New Zealand developed against a backdrop of acceleration, stretching and reshaping of Indigenous mobilities. Largescale movements of kin groups became increasingly common in the period between the mid-1810s and 1840 as a result of shifting economic behaviour, warfare and a long and complex sequence of migrations and displacements. Even though New Zealand was not formally incorporated into the formal operation of British imperial sovereignty until 1840, the reach of British, Australian and Euroamerican traders was a powerful magnet, drawing individuals, trading parties and kin groups to sites of sustained cross-cultural trade, such as Kāwhia, Kerikeri, Kororāreka, Tāmaki, Mahia and Kāpiti. These commercial engagements—which were important vectors for the introduction of new weapons, technologies, animals and plants-were a significant catalyst that helped to energise

16 Belich 1996; Standfield 2012; Te Punga Somerville 2012; Jones and Jenkins 2011; Cahir and Clark 2014; Jones and Jenkins 2011.

17 Binney 2004. 
a complex and sprawling sequence of military campaigns. From their base in the Bay of Islands and parts of the Hokianga, Ngāpuhi leaders initiated a series of devastating raids south to Tāmaki, Hauraki, Rotorua and down the east coast of Te Ika a Māui between 1819 and 1823. These raids were facilitated by Ngāpuhi's domination of cross-cultural trade. Ngāpuhi taua enjoyed a significant military advantage over their southern rivals as a result of their near monopoly on the musket trade (including with the rogue missionary Thomas Kendall), and their embrace of this new military technology allowed Ngāpuhi to seek utu (retribution, balance) for the various take (causes, issues) that underpinned this extended campaign of war making.

These increasingly extended raids to the south were further enabled by a significant shift in the material base of the tribe as a result of cross-cultural trade. By 1810, northern kin groups had embraced potato cultivation. Potatoes were much hardier than frost-sensitive kūmara (Polynesian sweet potato); this allowed rangatira to bring freshly cleared areas into cultivation to increase the output of production. Potatoes were also a key commodity in cross-cultural trade: they enabled groups in the Bay of Islands to access new tools and weapons from visiting European and American vessels. This encouraged rangatira to initiate large-scale potato cultivation that required a significant increase in labour inputs into production. ${ }^{18}$ The connections between the shift to potato production and the intensification of intertribal warfare in Te Ika a Māui between the 1810s and 1830s remains contentious; however, there is some evidence to suggest that potatoes were the significant material base that sustained a protracted sequence of military campaigns and, further, that their cultivation encouraged the expanded use of war captives as a labour force. ${ }^{19}$

Ngāpuhi were not the only moving force in this age of hyperactive motion; further south, Ngāti Toa also launched a prolonged sequence of raids and campaigns. In the wake of ongoing conflicts over the rich resources and trading opportunities in the Kāwhia region with their Waikato and Maniapoto rivals, Ngāti Toa pushed south to the Kāpiti region in the south-west of Te Ika a Māui in 1821-22. After asserting their authority in the battle at Waiorua in 1824, Ngāti Toa then launched a sequence of

18 Salmond 1997: 422 .

19 Ballara 2003: 397-98. Compare Ballara's cautious reading of the role of potatoes in providing the material base for the extension of Maori warfare-she suggests that they may have only become very significant in the 1830s_with Belich's more assertive reading: Belich 1996: 159. 
long-distance raids from their Kāpiti stronghold into Te Wai Pounamu from 1831 that significantly impacted the demographics, settlement patterns and politics of the south. Four years later, Ngāti Toa's close kin, Ngāti Mutunga and Ngāti Tama, who had been displaced from northern Taranaki, travelled to Rèkohu (Chatham Islands), where they swiftly asserted their dominance over the Moriori people. Taken together, these campaigns, migrations and displacements redrew the demographic and political maps of Te Ika a Māui, Te Wai Pounamu and Rēkohu.

This intense period of accelerated and extensive movement was largely closed down by the formal assertion of British sovereignty over New Zealand in 1840. British rule constrained some traditional forms of Māori mobility, closing off some ways of moving across the landscape while simultaneously fashioning a new matrix of roads, markets, towns and ports that inflected both 'traditional' practices and the pattern of Māori engagement with the colonial economy and state institutions. At the same time, British power worked to calcify rohe as 'traditional' domains of the 'great chiefs' of the 'tribes' that loomed so large in the imagination of the colonial state.

In exploring the 'entanglement' of missionary and Māori mobilities, it is crucial to recognise the ways in which missionaries had to accommodate themselves to Māori ways of moving and the rules governing mobility. Missionaries, like the whalers, traders and sailors who frequented New Zealand's coastlines, were inhabiting landscapes that were encoded with meaning. Given both their long-term commitment to living among Māori and their desire to ultimately create native churches, missionaries had to grapple with the weight of traditional beliefs and practices in ways that marked them off from other newcomers. Tapu - things that were set apart and 'sacred' because they were connected to the workings of atua (supernatural powers, gods) —was a powerful challenge for missionaries eager to establish the authority of their god and cosmology. Many scholars, including, most recently, Angela Middleton, have argued that missionaries attacked tapu and discounted as profane Māori beliefs that tapu was manifest in the local landscape. ${ }^{20}$ However, this argument is called into question by evidence of significant accommodations made on

20 Middleton 2008: 48-50. However, Middleton recognised that the missionaries were forced to make some accommodations to tapu in the early years of the mission. 
mission stations to the power of tapu in the Māori world. For example, in 1817, Thomas Kendall explained to Samuel Marsden that the mission's relationships with local peoples and landscapes were constrained by tapu, especially those practices associated with death:

In selecting a portion of land for a settlement, it would be advisable to take care that it be as clear as possible of what the natives call the wahhe taboo [wāhi tapu]. Wherever a person has breathed his last, or his bones have been laid for a time, there is always a piece of timber set up, if there is no tree already growing, to perpetuate his memory. This [wāhi tapu] is not suffered to be molested, and is held sacred both by friends and strangers. Amongst the natives, the least disrespect paid to their sacred relics or religious ceremonies and customs is considered a sufficient ground for a war by enemies and for a public debate by friends. ${ }^{21}$

As the Ngāpuhi elder and scholar Patu Hohepa has noted, traditional death ways had 'spread layers of tapu' over the terrain in the Bay of Islands. The region's landscape was studded with tapu sites where the deceased were prepared for display or burial, where exhumed bones were painted with ochre in preparation for secondary burial, and where bodies were buried and bones were finally interred. ${ }^{22}$ Kendall's letter underscores the degree to which missionaries apprehended the power of these practices and felt constrained by tapu's presence and power.

Kendall noted that the pioneering cohort of missionaries had inadvertently violated tapu, triggering conflict:

My colleague, Mr. Hall, and Mrs. Hall, suffered at Whitangee on account of the disrespect which had been paid by Warrakkee's people to some sacred relic, and not on account of any ill-will which the assailants entertained towards them. ${ }^{23}$

This referred to a taua muru (plunder party) that raided the Halls new base at Waitangi in January 1816. The toa (warriors) threw William Hall to the ground and threatened him with weapons; they struck Dinah Hall in the face when she came to her husband's aid, temporarily blinding her. The party then plundered the mission house, stripping it of its bedding and taking tools, cooking utensils, an axe and two guns. ${ }^{24}$ The plundering was a form of structured punishment. The Halls had unwittingly settled on land that had belonged to the recently deceased rangatira Waraki. It

21 Kendall 1817.

22 Hohepa 2007: 90.

23 Kendall 1817.

24 Hall 1816a. On taua muru see Ballara 2003: 103-11. 
seems that Waraki's death, together with the vulnerability of the Halls, provided an occasion for a rival group to exact utu for an earlier infraction of tapu by Waraki's people.

Even as they were fiercely critical of tapu, missionaries recognised its cultural power; they were generally very careful to avoid any infractions on wāhi tapu. Grant Phillipson has noted that in negotiations for the purchase of land by the CMS, missionaries affirmed that they would respect wāhi tapu. ${ }^{25}$ This understanding shaped how the missionaries ordered their own activity in the Bay of Islands, as they recognised that their own burials had to be undertaken with care. Essentially, the missionaries came to agree that burials at which they officiated had to occur within the boundaries of mission stations, thereby avoiding any implication that they were making claims to any other site through burials. This practice took shape from the winter of 1816, with the sudden death of Sarah Shergold. ${ }^{26}$ Although the missionaries had witnessed many Māori deaths in the first 18 months of their work, Shergold was the first European to die since the establishment of the mission. William Hall spent a full day constructing a coffin and preparing the grave, which was dug at an unspecified location within the station at Hohi. ${ }^{27}$

Thus, quite quickly, the fledgling missionary community came to understand that they were living in a landscape brimming with history and meaning. In the early years of the mission, they felt very much under the control of their powerful chiefly patrons and that they had limited ability to move and act independently. The early mission stations were located at sites selected by their chiefly patrons. The first missionary settlement was established under the mantle of the rangatira Ruatara on narrow terraces at Hohi under the Ruatara's stronghold, the pà (fortified settlement) at Rangihoua. Ruatara was vital to the foundation of the mission: he had a close relationship with Samuel Marsden, he brokered amicable relationships for the mission with other northern kin groups and he guided Marsden on his travels in New Zealand. Ruatara also enabled the mission to be established in such a politically influential site as Rangihoua. The great rangatira, Hongi Hika, also had strong connections there. Ruatara and Hongi placed clear parameters and constraints on the development of the mission. The complex of simple buildings erected at

25 Phillipson 2007: 64.

26 Hall 1816b: 25 July 1816.

27 Hall 1816b: 25 July 1816. 
Hohi was positioned so that the mission was under constant surveillance from the pā. Moreover, the narrow terraces they occupied provided limited productive land and no easily accessible space for future growth.

The pioneering missionaries Thomas Kendall and John King were all too aware of the implications of this arrangement; they could not be selfsustaining and were forced to rely on the CMS to provide them with goods to trade with local Māori. Kendall complained in 1815:

We have now resided nearly two years at this place, and to all appearances there is no probability of our obtaining the necessaries of life in any other way than at the expense of the Society. The spot on which we live is barren, and $\ldots$ is so mountainous that it is quite unsuitable for the purpose of cultivation or for cattle. ${ }^{28}$

The inability of the missionaries to farm or garden meant that they remained heavily dependent on influential rangatira such as Hongi. From the very beginning of the mission, Hongi had tried to persuade Marsden that a missionary settlement should be established at Kerikeri, in the north-west corner of the Bay of Islands where the Kerikeri River flowed into a sheltered basin. Hongi's mana extended over this location, as his father, Te Hotete, had occupied the adjacent Kororipo pā in the 1790s. ${ }^{29}$ This pā not only had commanding views of the basin and the bay, it also stood at the hinge between the ocean and the land, guarding the primary pathway to the significant centres of settlement and cultivation in the interior, including Hongi's great pā Ōkuratope. Kerikeri was at the heart of Hongi's growing power in the 1810s and 1820s. It provided access to excellent fishing and had excellent gravel-rich soils; it also served as a key military centre. It was the base from which Hongi launched his sequence of campaigns to the south and his taua returned to Kerikeri from war with their captives. ${ }^{30}$

Marsden and Hongi agreed in 1815 that the missionaries based at Hohi would be able to plant wheat at Kerikeri in the following spring, signalling that a formal connection was developing between the mission and the site. ${ }^{31}$ Hongi worked hard to extend the relationship. During Marsden's second visit to Te Ika a Māui in 1819, Hongi took him and a group

28 Kendall 1816a.

29 Sissons 2007: 47.

30 Binney 2007: 10-12.

31 Sissons 2007: 47. 
of missionaries up the Kerikeri River and formally offered the mission the right to use any lands that suited their purposes. The evangelical party was delighted by the site. Marsden observed that the soil was:

Rich, the land pretty level, free from timber, easy to work with the plough and bounded by a fine freshwater river, and the communication by water free and open to any part of the Bay of Islands. ${ }^{32}$

The missionaries' desire to establish a permanent settlement at Kerikeri underlined, and further enhanced, the mana of Hongi. He rightly believed that having a mission station at Kerikeri would draw new flows of European goods into his domain and cement his domination over crosscultural trade in the bay. Moreover, he knew this commercial advantage might enhance the military superiority of his kin, as controlling the reach of imperial trading networks into northern New Zealand would assist Hongi in sustaining the resource-hungry military actions he continued to launch against his rivals and competitors far to the south.

The implications of these shifts in the lines of trade were clearly understood by rival chiefs and kin groups. Korokoro, a Ngare Raumati chief whose authority rested in the coastal lands on the south side of the bay and in the islands in the east of the region, complained to Marsden about the impact of placing a mission station at Kerikeri. He explained that it was marginalising his people while consolidating Hongi's strategic advantage-a shift that was disrupting the relationships between kin groups in the region. Marsden noted that Korokoro believed that it was too great an affliction for all the Europeans to reside with Shunghee'. Marsden worked hard to placate Korokoro's concerns, visiting Korokoro's people near Paroa on the south side of the bay. Marsden promised to consider locating a mission near Paroa in the future, thereby rebalancing the circuitry of trade-a possibility that was never realised. ${ }^{33}$

In the 1820s, Hongi's relationships with the missionaries became increasingly tense as a result of his abiding links to the transgressive Thomas Kendall, who was removed from the mission in 1822. To Hongi's frustration, most missionaries, unlike Kendall, refused to engage in the musket trade or aid in having the weapons repaired. Nevertheless, a symbiotic relationship persisted between the great chief and the mission until Hongi's death in 1828, even if Hongi was less enthusiastic about Christian teaching than the benefits of trade.

32 Marsden 1819a.

33 Marsden 1819b. 
By the end of the 1820s, Kerikeri and Hohi, especially the latter, had diminished as centres of Māori population and been eclipsed as primary trading centres. Ongoing missionary complaints about the limits of the Hohi site ultimately convinced the CMS to approve the mission on the north side of the bay to relocate a short distance to the west to Te Puna, a site that Kendall had preferred since $1815 .{ }^{34}$ While Te Puna had greater agricultural potential, in reality, oscillations in the economic and social geography of the bay had made both Hohi and Te Puna relatively marginal. The pull of Hongi's power, especially inland at Ōkuratope, shifted the political geography of the region. At the same time, the prominence of Kororāreka (on the south side of the bay) as an anchorage and site of cross-cultural trade in weapons, tools, alcohol and sex meant that Te Puna was no longer the 'capital' of the bay, as it had been in the first decade of the nineteenth century under Te Pahi's influence. ${ }^{35}$

The north side of the bay was increasingly overshadowed as a consequence of the changing geography of missionary settlements and, in particular, the growing importance of the Paihia mission founded in the southwest. The mission's new leader, Henry Williams, was concerned at what he understood as the missionaries' dependence on, and subordination to, Māori powerbrokers. From the time of his arrival in New Zealand, Williams was also frustrated by the mission's reliance on the unreliable service provided by visiting ships and trade at Kororāreka. The station, established in 1823 at Paihia on the banks of the Kawakawa River in the south-west of the bay, put the mission on a more secure foundation. Chosen by Williams and Marsden, Paihia was a site that the missionaries saw as a new beginning for the mission. It was selected, in part, because of strong personal connections between Marsden and a key local rangatira, Te Koki. In Marsden's account of his visit to Paihia in August 1823, he noted that Te Koki, a 'very worthy man', had spent time with him at Parramatta. ${ }^{36}$ Their personal bond was quite substantial; after Te Koki's son, Te Ahara, died at the Parramatta Native Institution, Marsden gave an undertaking that he would send a missionary to Te Koki and his people. ${ }^{37}$ Williams understood the strength of the bond that underpinned the foundation of the missionary settlement at Paihia, for even as he hoped to secure more independence for the mission, he understood that 'the missionary

34 Kendall 1816a.

35 Middleton 2008: 69.

36 Marsden 1823a.

37 Rogers 1961: 31, footnote 1. 
becomes one with the tribe with which he is connected'. ${ }^{38}$ In addition to discharging this important personal obligation, the foundation of the mission at Paihia suggests that Marsden remained aware of the importance of balancing the interests of the kin groups on either side of the bay, even if he could not satisfy Korokoro's desire for a mission at Paroa. Te Koki was connected to Pomare, Tara and Te Morenga, important chiefs and key figures in the 'southern alliance' of hapu that controlled the southern and south-western sections of the bay.

It quickly became clear that the Paihia site was extremely advantageous, providing the mission with a secure material base that placed it at the centre of a new set of expansive networks. The mission was built on good, flat ground that sustained an excellent garden and orchard. It also had access to excellent local sites for fishing and gathering shellfish, a sheltered beach and good lines of sight across the bay. ${ }^{39}$

Given the importance of these maritime connections, it is hardly surprising that the extension of the mission's shipping capacity was a high priority. Soon after his arrival, Williams committed the mission to constructing its own New Zealand-based vessel in an effort to limit the mission's dependence on Māori and on the rhythms of trans-Tasman shipping. Under Williams' oversight, Māori workers played a key role in the construction of a schooner named the Herald. The vessel, which was constructed on the beach at Paihia, greatly enhanced the ability of the missionaries to initiate and directly control communications with New South Wales. It was equally significant in recalibrating social relations within Te Ika a Māui, as it enabled missionaries and their 'native teachers' to travel long distances with relative speed; it also allowed the mission to extend its influence down the east coast to Tauranga and the west coast via the North Cape. ${ }^{40}$ As well as carrying the Gospel to new frontiers of evangelisation, the missionaries were able to exercise much more control over the movement of food, livestock, tools and trade goods that were the lifeblood of the mission. The Herald fundamentally reordered the economics of the mission, as it could now trade directly with more isolated hapū and iwi who accepted fishhooks as a medium of exchange rather than demanding muskets. The mission enjoyed greater security and its standing (mana) was enhanced, as the accumulation of food and

40 Middleton 2008: 225. 
valued objects was a key marker of power and status in the Māori world. In 1825, Williams noted that the missionaries would no longer be at 'their wits' end for common necessaries', which meant that they would be much less dependent on Te Koki-who had effectively been their 'liege lord'. ${ }^{41}$ Thus, the Herald allowed the mission to begin to temper the power of the chiefly patrons who exercised so much control over the mission's early development. The enhanced commercial capacity and confidence that flowed from it enabled the missionaries to become more assertive in emphasising the value of the Gospel, the power of the Christian God and the need for Māori to embrace 'new' ways of thought and action.

The establishment of a mission station inland at Waimate in 1831 marked a dilution of the mission's dependence on chiefly patrons and protectors. Even though the Waimate mission, like the one at Paihia, had its genesis in Marsden's connection with Hongi, the missionaries there had no 'liege lord'. It was a site where Hongi exercised power. Marsden and his party had been greatly impressed when Hongi showed them the päs triple palisades and the 30 acres of potatoes and kūmara planted around the pā in 1815.42 Marsden encouraged Hongi to develop this agricultural capacity; in an 1823 letter, he promised to provide Hongi with tools and seeds for new cultivations at Waimate. Marsden stressed that agricultural improvement should be the rangatira's priority, and that he should build his mana through cultivation and the provision of food, not raiding to the south: 'Then you will become a very great man and will be able to feed and clothe many people'. ${ }^{43}$ In 1824, Marden sent the missionary farmer Richard Davis to New Zealand. He introduced Davis to Hongi as 'a gentleman who would be able to make a farm at Wymatte [sic]'. ${ }^{44}$ A successful tenant farmer from Dorset, Davis taught Hongi's people how to use a plough and bullocks, cultivate wheat and produce flour. In the 1830s, the Waimate station developed in keeping with Davis' vision of a mixed English farm of some 250 acres. However, the mission had difficulty sourcing adequate labour, it was undersupplied with suitable tools and its livestock were vulnerable to attacks by dogs owned by local Mãori. In the early 1840s, it was converted by the newly arrived Bishop Selwyn into an educational establishment. ${ }^{45}$ Nevertheless, Waimate was

41 Williams, journal entry, 6 January 1825, cited in Fitzgerald 2011: 52-53.

42 Nicholas 1817: i, 333.

43 Marsden 1823b; Parsonson 1980.

44 Marsden 1824.

45 Hargreaves 1962. 
a crucial experiment that demonstrated the ability of missionaries to pursue their own model of economic organisation-a degree of autonomy that increased the appeal of Christianity and the influence of missionaries as both peacemakers and agents of social change more broadly. ${ }^{46}$

\section{$\star \star \star$}

While the development of missionary settlements was deeply embedded in the changing economic and social geography of northern Te Ika a Māui, and played a key role in shaping lines of trade and movement across and beyond the Bay of Islands, they also rerouted patterns of mobility on a smaller scale at a daily level. Entanglements of Empire emphasised the ways in which mobility structured the everyday relationships between missionaries, mission workers and Māori, underwriting the daily routines of missionary labour; the book also stressed the pivotal role that mobility played in shaping the nature of mission stations. Arguing against the tendency in the existing historiography to see the stations as enclosed European or British spaces separated from the Māori world by fences, it noted both the persistent insecurity of the stations and the regular pulses of movement that wove them into local society. ${ }^{47}$

Rather than focusing on fences as cultural boundaries and barriers, it is important to remember that the gates to the station enabled connection. The opening of the gates enabled and directed the quotidian mobilities of life on mission stations to unfold. Indeed, we might follow Anna Tsing's formulation and understand the mission's gates as channelling the 'friction' that was an integral part of these entanglement of cultures, shaping the 'grip of worldly encounter' ${ }^{48}$ Māori from local settlements or more distant communities would enter into missionary settlements to undertake work in, or around, the houses, in the workshops, at the sawyer's pit, blacksmith's shop or in the gardens and fields. Children, youths and adults would come into stations for school or more informal lessons, as well as for prayer and formal services. More irregular traffic brought influential visitors: chiefly patrons and Māori leaders from distant communities, British officials, European travellers and European and American sea captains. 
Things also moved in and out of the gates. Māori brought fish and shellfish into the stations, providing an important food source for the mission. Kai moana (seafood) was just one element in a steady traffic of food and animals: poultry, livestock and horses came into the mission and went out again, as did seeds, seedlings and new food plants. While iron and building materials (timber, raupo and fern) were brought into the stations, nails, toki (adzes), and simple tools moved out of the smithy, as did sawn timber from the sawyers' pits and furniture from William Hall's workshop. In addition, many Māori carried beads, cloth, clothes, hats, soap, food and fishhooks-important gifts, rewards and payments given by missionaries-back to their communities, meaning that the material framework of the mission was increasingly woven into the life ways of Māori communities. The Gospel too moved in and out of the mission; missionaries and native teachers who travelled out to itinerate around the bay, or to visit new frontiers where missionaries were not yet formally established, carried printed texts, while many Māori who visited the mission left carrying printed portions of Scripture. ${ }^{49}$

These on-the-ground economic relationships were dependent on maritime connections that provided the mission with trade goods. Ships and shipping were the lifeblood of the mission; however, they were also a constant concern, both to missionary families and to Marsden who, over the long run, became adept at coordinating mail and the movement of goods and people through a patchy and irregular set of oceanic networks. Until 1830, all of the mission stations were littoral communities, reflecting the importance of shipping to their function. Missions were hubs visited by Māori waka, mission ships and other vessels that called at the Bay of Islands. After unloading their cargoes of tools, people, seeds, animals, foodstuffs, commodities, clothes, materials, shoes, books, mail and so on, European ships loaded letters, ethnographic artefacts, missionary travellers and their families, and Māori guides and political brokers (such as Ruatara and Te Morenga). In turn, this maritime traffic articulated with shipping and commercial networks centred on Port Jackson, expansive trans-Pacific trading networks and the global commercial traffic fashioned by the British Empire. These connections underwrote the governance of the mission through correspondence, and were crucial in allowing missionaries to maintain their own familial networks. 
Paper was one of the key instruments that came to shape social relations in and around the mission. Paper was central to the development of plans for the mission, underwriting its eventual foundation and directing its subsequent growth. The movement of paper framed the physical extension of evangelisation in the 1830s: north towards Kaitaia, south towards Manukau, the Waikato, the area around the Waihou River, Tauranga and to the East Cape, and further south to Otaki. Letters of persuasion and argument, committee minutes, and instructions and directives framed a strategy of expansion; these paper instruments moved expansively, by foot and on horseback, and on waka and ships within Te Ika a Māui and beyond to Port Jackson and London. The expansion of the mission was also pushed forward by Māori themselves; influential chiefs wrote beseechingly, requesting missionaries, teachers and schools, while native catechists carried the Gospel far beyond the frontiers of the mission's circuits of itineration, and new converts spread the Christian message through texts and oral conversation.

It is important to assess the connections between mobility, paper and literacy in the 1810s-a period that the historiography has characterised as long predating the formal impact of Christianity, literacy and the printed word. Paper is a recurrent concern in the early letters and journals of the missionaries, reflecting its importance to their daily practices. When Thomas Kendall wrote to the CMS in October 1816, he requested a bell for the school and outlined the various types of paper he required: 'Post \& Letter Paper that will bear ink well. I am almost entirely without. The paper intended for me was used on account of the New Zealanders first Book at Port Jackson'. He also requested:

3 Doz copy Books Extra paper

3 Doz Foolsc for the Settlers Children \& ciphering Books Extra paper ...

Quills \& copy Books \& Ink for the Native children. ${ }^{50}$

In a December 1818 letter, Kendall noted that he 'wanted for the Native Boys':

6 reams of writing paper that will bear ink well

6 Quires of paper for Copy Book covers

12 papers of ink powder

6 Lead Ink stands

1000 Quills. ${ }^{51}$

50 Kendall 1816b.

51 Kendall 1818. 
Through the mission's writing exercises and its quills, ink, pencils, slates and paper, literacy became a significant component of the northern Māori world by 1820 ; its reach was extended, deepened and further democratised in the 1820 s and $1830 \mathrm{~s}^{52}$ There is some evidence that suggests that literacy was part of the novel, cultural package that made Christianity attractive to some Māori and that its accoutrements (i.e. paper and pens) were valued by those Māori who saw the mission primarily as an opportunity to access new technologies and skills (Hongi Hika is an excellent example of that dynamic). These new media and novel skills were woven into many aspects of Māori life, being used to communicate ideas and news across long distances; they were pivotal in concluding agreements of various kinds with missionaries, traders and other newcomers; they were woven into bodily adornment and decorative schema, sometimes functioning as talisman; and were intimately connected with the spread of Christian thought and teaching. As I have shown elsewhere, the chronological and geographical spread of the 'culture of paper' was regionally particular-the pattern in the far south diverged from the north in significant ways-but what is particularly important here is the distinctive materiality of paper when viewed against the media that underwrote the traditional Màori knowledge order. ${ }^{53}$

While it is commonplace to designate Māori culture as 'oral', in reality, the pre-European peoples of Te Ika a Māui and Te Wai Pounamu stored and encoded knowledge in a range of objects. Prior to the arrival of Europeans, the knowledge-bearing objects of the people of Te Ika a Māui were typically made out of wood, bone, or pounamu (jade), and their cultural value was underlined by their highly worked nature. Important knowledge was encoded into the elaborate carvings that decorated houses and meeting places, the ornamentation on treasured weapons and musical instruments, the forms of various worked figures used for architectural or personal ornamentation, and into rākau whakapapa (genealogical rods or staffs). Such objects often stored information about community history (especially key ancestors) or the connections between atua (supernatural powers or gods) and the human world. Often the physical form of these objects or decorative schema operated as a prompt, providing a starting point or framework for a narrative, rather than an entire narrative or body of knowledge. Rākau whakapapa did not provide the names and

52 Middleton 2008.

53 Ballantyne 2011a. 
relationships of all ancestors; instead, their carved form provided a physical framework for the recitation of genealogy. Thus, they functioned as both an incitement to kōrero (speech) and a way of organising recall and recitation. They were tangible physical guides around which genealogical information could be recalled, organised and recited. The construction of these objects in hard-wearing materials meant that they were long lasting and could not easily be changed or revised; they were valuable because of their particularity and durability. As such, these objects were well suited to communicating knowledge across time. Within the analytical framework of Harold Innis' pioneering studies of media and communication, these objects were 'time-binding'; they enabled the transmission of knowledge between the generations, embodying the validity of traditional knowledge and the cultural authority of those who mastered such bodies of information and understanding. ${ }^{54}$

Conversely, the order championed by missionaries was expansive-it was geared to communication across space, connecting missionaries in New Zealand to the dispersed communities among whom they itinerated, to Marsden and the colonial authorities in New South Wales and to the CMS's secretaries in London. Generally speaking, the missionaries valued literacy, paper and printing; media and knowledge that were geared towards transcending physical space; and sharing news, information, knowledge and ideas over long distances.

Harold Innis termed these kinds of activities and aspirations 'spacebinding knowledge practices'. As I have observed elsewhere, this incoming order tended to value the attainment of education over rank and celebrate exchange and debate rather than retention; it was oriented towards the expansiveness of a dispersed empire and global community of Protestantism over the confines of a local community defined by genealogical ties. ${ }^{55}$ Fundamentally, the missionaries valued mobility, motion and the open movement of ideas-dynamics that were central to the British evangelical revival and that, as Joel Mokyr has shown, encoded British economic thought and practice in the early nineteenth century. ${ }^{56}$ However, we must guard against seeing these knowledge orders as fixed, rigid and slow moving, for there is strong archival evidence to point to the ability of Māori to quickly deploy and rework new ideas, technologies

54 Innis 1950; Innis 1951.

55 Innis 1950; Innis 1951.

56 Mokyr 2009. 
and skills on the mission stations-evidence that reinforces Michael Stevens' recent arguments about the porousness and flexibility of Māori mentalities and practices. ${ }^{57}$

The 'culture of paper' was more than the connective tissue of the mission, it was also central to the mission's ability to 'account' - a flexible verb that encompassed the provision of descriptive written narratives, the creation of records of stock, income and expenditure and, even more specifically, a particular type of bill. Missions were a type of bureaucratic regime and 'accountability' was a significant component of the mission's function. Accounting for the dispersal of gifts and items of trade was a constant concern within the archives of the CMS in New Zealand in the 1810s and 1820 s.

Writing also was a way of keeping track of Māori, especially for the schoolteacher Thomas Kendall and his assistant, William Carlisle. Their roll for the Rangihoua school in October 1816 recorded the attendance of some 51 pupils. The document shows the extent to which the missionaries had to accommodate the rhythms of movement that were integral to Māori social and economic life. For example, 'A Hooia' missed school for the second half of the month as she was 'on a journey'; 'Ka dooa' left the school altogether having 'gone to Whitianga'; 'A Keena' missed a week of lessons while they were 'on a journey'; 'Taa hoo horo' did not attend in the middle of the month for the same reason; 'A Hoongha', 'Titeedoea', 'A Peeko' and 'A Too' were all absent for the entire month while they were 'at the sweet potato grounds'; and 'A Hei', 'A Kahou', 'A Moe', 'Na Motoo', 'Heena Hoodoo' and 'A Ranee' all missed instruction as they were recorded as being 'at work' for periods of time. The school records give a sense of motion and movement and the bustling rhythms of agriculture, trade and travel. Pupils moved in and out of the school and some, such as 'Ranghee Totto', whose 'residence' was noted as being at a 'great distance', travelled extensively to attend the school. Kendall and Carlisle noted:

The weather being generally fine and pleasant during the present month and the Natives of Ranghee Hoo [being] busy in preparing the Grounds for the purpose of planting sweet Potatoes, many Scholars have been occasionally absent. We have been also under the necessity of following several of our pupils into the Bush, where we have taught them their

57 Stevens 2011; Stevens 2015; Ballantyne 2014b. 
Lessons. We have promised to each Scholar a set of Beads as rewards with a view to prevent them leaving the School house as little as possible. The children are to attend one month for the Beads. ${ }^{58}$

On 19 August 1816, the missionaries noted that attendance at the school was low, as several students were 'absent procuring cockles'. Schooling was also interrupted by visitors. On 21 August, it was noted that 'interuptions [sic] from the Chief Werea and his party' were a distraction; three days later, the school was 'visited by the chief Toutaddee $\&$ family'. A brief note for 29 August-'Kumokuno, Shunghee \& their party'-suggests that further interruptions followed. On 16 and 17 September, successive entries noted: 'A party of Scholars absent procuring cockles; Several Scholars in the Sweet Potato grounds in the day time'. ${ }^{59}$ This suggests that, while mission stations redrew lines of connection within the northern Māori world as they became significant centres of trade (including muskets), they had little impact on the mobilities, large and small, that underwrote the predominant patterns of Māori labour until at least the early $1820 \mathrm{~s}^{60}$

Early printed texts, such as A Grammar and Vocabulary of the Language of New Zealand (1820), suggest that the foundation of the mission recalibrated some of the possibilities for mobility. Although traditionally attributed to Thomas Kendall in collaboration with the Orientalist linguist Professor Samuel Lee, recent work by Alison Jones and Kuni Jenkins has reframed the Grammar as a kind of co-creation or co-production strongly imprinted by Kendall's travelling companions, Hongi Hika and Waikato, and by Kendall's earlier Māori teachers. ${ }^{61}$ The Grammar is shot through with movement: people come and go, meet, return and depart. One of the verbs used to illustrate various moods is 'aire' ('haere'): to travel, walk, continue, depart and, when followed by 'mai', to come. ${ }^{62}$ Of course, 'to go' is a basic grammatical construction in many languages; however, the prominence of this perhaps reflects the mobility of missionaries and their Mãori patrons, as well as the frequent meetings and encounters with new peoples that were integral to evangelisation-moments loaded with possibility and danger within te ao Māori (the Māori world). The Grammar features dialogues and vocabulary connected to ships, journeys, rivers, harbours and travel, both over short and long distances. One dialogue

58 Church Missionary Society 1816a.

59 Church Missionary Society 1816 b.

60 Ballantyne 2014b.

61 Jones and Jenkins 2011.

62 Kendall 1820: 35-45. 
discusses Hongi's departure for England and his planned return. New vocabulary related to European transportation technologies, such as 'a cabin of the ship' ('E páre-máta no te kaipúke'), were prominent. ${ }^{63}$ So too was a sense of confidence and power. Another of the dialogues asks about the voyage of Hongi and his party to England: 'what are they going to do'? The answer is revealing:

Ko te títiro átu óki ki te pai o te wenúa óki, kit e ánga o te pakeha óki, ki te tíni o te tángata óki.

To see the goodness of the land, the occupations of the people, the number of the inhabitants. ${ }^{64}$

Here the imperial gaze was reversed. It was the powerful Māori rangatira who were crossing the world to assess and evaluate distant lands. While this journey allowed Kendall to shore up his relationship with Hongi, who had emerged as the most powerful of the leaders in the Bay of Islands, the two rangatira made their motivations for this trip clear. Soon after their arrival in England, Kendall recorded their demands. Kendall was to aid them in putting together a party of men to 'dig up the ground' in search of iron ore, and to gather more 'preachers' and 100 settlers to be taken to New Zealand. The missionary was also to furnish the chiefs with a large dog each as a marker of their mana, and to recruit a contingent of 20 soldiers accompanied by three officers. ${ }^{65}$ With its references to 'Ingland' (England), 'Port Jákson' (Port Jackson) and 'Paramáta' (Parramatta), the Grammar captures the expansion of te ao Màori. If the human world is te ao hurihuri (the changing or turning world), then the establishment of the CMS mission, the engagement of Māori with the global reach of British missionary and imperial networks, and their growing interest in the Bible (as a deep and expansive store of stories), simultaneously stretched that world in range of ways. Books and ships, pens and paper, and Bibles and maps became important parts of Indigenous life, and proved to be central in reordering relationships within and between communities over the subsequent decades as Mãori grappled with the opportunities and terrible dangers of an expanded te ao hurihuri-a mobile and connected world.

63 Kendall 1820: 69.

64 Kendall 1820: 97.

65 Church Missionary Society 1820. 


\section{References}

Adshead, S.A.M. 1997, Material Culture in Europe and China, 1400-1800: The Rise of Consumerism, Macmillan, Basingstoke. doi.org/10.1007/ 978-1-349-25762-1

Ballantyne, Tony 2005, 'Religion, difference, and the limits of British imperial history', Victorian Studies 47(3): 427-55. doi.org/10.2979/ VIC.2005.47.3.427

Ballantyne, Tony 2011a, 'Paper, pen, and print: The transformation of the Kai Tahu knowledge order', Comparative Studies in Society \& History 53(2): 232-60. doi.org/10.1017/S0010417511000041

Ballantyne, Tony 2011b, 'On place, space and mobility in nineteenthcentury New Zealand', New Zealand Journal of History 45(1): 50-70.

Ballantyne, Tony 2013, 'Indien und die globalisierung kolonialen wissens', in Von Käfern, Märkten und Menschen: Kolonialismus und Wissen in der Moderne, Rebekka Habermas and Alexandra Przyrembel (eds), Vandenhoeck \& Ruprecht, Göttingen: 115-25. doi.org/10.13109/ 9783666300196.115

Ballantyne, Tony 2014a, 'Contesting the empire of paper: Cultures of print and anti-colonialism in the modern British Empire', in Indigenous Networks: Mobility, Connections and Exchange, Jane Lydon and Jane Carey (eds), Routledge, London: 219-40.

Ballantyne, Tony 2014b, Entanglements of Empire: Missionaries, Maori and the Question of the Body, Duke University Press, Durham. doi.org/ $10.1215 / 9780822375883$

Ballantyne, Tony 2014c, 'Mobility, empire, colonisation', History Australia 14(2): 7-37.

Ballantyne, Tony 2016, 'Moving texts and "humane sentiment": Materiality, mobility and the emotions of imperial humanitarianism', Journal of Colonialism and Colonial History 17(1). doi.org/10.1353/ cch.2016.0000 
Ballantyne, Tony and Antoinette Burton 2009, 'The politics of intimacy in an age of empire', in Moving Subjects: Gender, Mobility, and Intimacy in an Age of Global Empire, Tony Ballantyne and Antoinette Burton (eds), University of Illinois Press, Urbana: 1-28.

Ballara, Angela 2003, Taua: 'Musket Wars', 'Land Wars' or Tikanga?: Warfare in Maori Society in the Early Nineteenth Century, Penguin Books, Auckland.

Belich, James 1996, Making Peoples: A History of the New Zealanders: From Polynesian Settlement to the End of the Nineteenth Century, Penguin, Auckland.

Binney, Judith 2004, 'Tuki's universe', New Zealand Journal of History 38(2): 215-32.

Binney, Judith 2007, 'Introduction', in Te Kerikeri 1770-1850: The Meeting Pool, Judith Binney (ed.), Bridget Williams Books, Wellington.

Cahir, Fred and Ian Clark 2014, 'Aboriginal and Maori interactions in Victoria Australia, 1830-1900: A preliminary analysis', New Zealand Journal of History 48(1): 109-26.

Church Missionary Society 1816a (October), 'List of School Children', Samuel Marsden Collected Papers, Hocken Collections, University of Otago, Dunedin, MS 0056/028.

Church Missionary Society 1816b, 'Monthly Account of the Attendance of the Native Children at the Church Missionary Society's School, Bay of Islands New Zealand commencing August 12th. 1816; For September 1816', Samuel Marsden Collected Papers, Hocken Collections, University of Otago, Dunedin, MS 0056/023.

Church Missionary Society 1820, 'Objects of Shunghee and Whykato in Visiting England', Church Missionary Society, Archives Relating to the Australian and New Zealand Missions, 1808-1884, Mission Books Containing Correspondence to the CMS, CN/M1, Hocken Collections, University of Otago, Dunedin.

Clifford, James 1992, 'Travelling Cultures', in Cultural Studies, Lawrence Grossberg, Cary Nelson and Paula Treichler (eds), Routledge, New York: 96-116. 
Fitzgerald, Caroline 2011, Te Wiremu—Henry Williams: Early Years in the North, Huia, Wellington.

Fitzgerald, Tanya 2001, 'Fences, boundaries and imagined communities: Re-thinking the construction of early mission schools and communities in New Zealand 1823-1830', History of Education Review (30)2: 14-25.

Hahn, Hans Peter and Hadas Weis 2013, 'Introduction: Biographies, travels and itineraries of things', in Mobility, Meaning and Transformations of Things, Hans Peter Hahn and Hadas Weis (eds), Oxbow Books, London.

Hall, William 1816a (26 January), Letter to Samuel Marsden, Samuel Marsden Collected Papers, Hocken Collections, University of Otago, Dunedin, PC 0129.

Hall, William 1816b, Private Journal of William Hall, 1816-1838, Alexander Turnbull Library, National Library of New Zealand, Wellington, Micro-MS 0853.

Hamilton, Carolyn 1998, Terrific Majesty: The Powers of Shaka Zulu and the Limits of Historical Invention, Harvard University Press, Cambridge, MA.

Hargreaves, R.P. 1962, 'Waimate-pioneer New Zealand farm', Agricultural History 36 (1): 38-45.

Hohepa, Patu 2007, 'Kerikeri, Tapu, Wahi Tapu', in Te Kerikeri 1770 1850: The Meeting Pool, Judith Binney (ed.), Bridget Williams Books, Wellington. doi.org/10.7810/9781877242380_9

Innis, Harold 1950, Empire and Communications, Oxford University Press, Oxford.

Innis, Harold 1951, The Bias of Communication, University of Toronto Press, Toronto.

Jolly, Margaret 2001, 'On the edge? Deserts, oceans, islands', The Contemporary Pacific 13(2): 417-66. doi.org/10.1353/cp.2001.0055

Jones, Alison and Kuni Jenkins 2011, Words Between Us—He Körero: First Mãori-Pakeha Conversations on Paper, Huia, Wellington. 
Kendall, Thomas 1816a (6 November), Letter to Secretary of CMS, Samuel Marsden Collected Papers, Hocken Collections, University of Otago, Dunedin, PC 0130.

Kendall, Thomas 1816b (28 October), Letter to Reverend Josiah Pratt, Samuel Marsden Collected Papers, Hocken Collections, University of Otago, Dunedin, MS 0056/025.

Kendall, Thomas 1817 (25 July), Letter to Samuel Marsden, Samuel Marsden Collected Papers, Hocken Collections, University of Otago, Dunedin, PC-0131.

Kendall, Thomas 1818 (8 December), Letter to Reverend Josiah Pratt, Samuel Marsden Collected Papers, Hocken Collections, University of Otago, Dunedin, MS 0056/210.

Kendall, Thomas 1820, A Grammar and Vocabulary of the Language of New Zealand, Church Missionary Society, London.

Marsden, Samuel 1819a (17 August), Journal, 'Rev. S. Marsden's Journal of Proceedings at New Zealand from July 29 to Oct 19, 1819', Samuel Marsden Collected Papers, Hocken Collections, University of Otago, Dunedin, PC 0140.

Marsden, Samuel 1819b (18 August), Journal, 'Rev. S. Marsden's Journal of Proceedings at New Zealand from July 29 to Oct 19, 1819', Samuel Marsden Collected Papers, Hocken Collections, University of Otago, Dunedin, PC 0140.

Marsden, Samuel 1823a (7 August), Journal, 'Rev. S. Marsden's journal from July 2 to Nov 1, 1823', Samuel Marsden Collected Papers, Hocken Collections, University of Otago, Dunedin, MS 0177/003.

Marsden, Samuel 1823b (11 November), Letter to Hongi, in Letters and Journals of Samuel Marsden, J.R. Elder (ed.), Coulls, Somerville, Wilkie, Dunedin.

Marsden, Samuel 1824 (26 July), Letter to Hongi, in Letters and Journals of Samuel Marsden, J.R. Elder (ed.), Coulls, Somerville, Wilkie, Dunedin.

Middleton, Angela 2008, Te Puna-A New Zealand Mission Station: Historical Archaeology in New Zealand, Springer, London. doi.org/ 10.1007/978-0-387-77622-4 
Mokyr, Joel 2009, The Enlightened Economy: An Economic History of Britain, 1700-1850, Yale University Press, New Haven.

Nicholas, John Liddiard 1817, Narrative of a Voyage to New Zealand Performed in the Years 1814 and 1815, James Black \& Son, London.

Nuttall, Sarah 2009, Entanglement: Literary and Cultural Reflections on Post Apartheid, Wits University Press, Johannesburg.

O'Malley, Vincent 2015, Haerenga: Early Maori Journeys Across the Globe, Bridget Williams Books, Wellington.

Parsonson, Ann 1980, 'The expansion of a competitive society', New Zealand Journal of History 14(1): 45-60.

Phillipson, Grant 2007, 'Religion and land: The Church Missionary Society, 1819-50', in Te Kerikeri 1770-1850: The Meeting Pool, Judith Binney (ed.), Bridget Williams Books, Wellington.

Rogers, Lawrence M. (ed.) 1961, The Early Journals of Henry Williams: Senior Missionary in New Zealand of the Church Missionary Society 1826-40, Pegasus Press, Christchurch.

Salesa, Damon 2003, “Travel-happy” Samoa: Colonialism, Samoan migration, and a "brown Pacific", New Zealand Journal of History 37(2): 171-88.

Salesa, Damon 2013a, 'Pacific in Indigenous time', in Pacific Histories: Ocean, Land, People, David Armitage and Alison Bashford (eds), Palgrave, Basingstoke.

Salesa, Damon 2013b, 'Passages in a native sea: Some Indigenous histories of globalization in the Pacific', J.C. Beaglehole Lecture, New Zealand Historical Association Conference, Dunedin.

Salmond, Anne 1997, Between Worlds: Early Exchanges between Maori and Europeans 1773-1815, Viking, Auckland.

Sheller, Mimi and John Urry 2006, 'The new mobilities paradigm', Environment and Planning A 38: 207-26. doi.org/10.1068/a37268

Sissons, Jeffrey 2007, 'Hongi Hika', in Te Kerikeri 1770-1850: The Meeting Pool, Judith Binney (ed.), Bridget Williams Books, Wellington. doi.org/ 10.7810/9781877242380_5 
Standfield, Rachel 2012, Race and Identity in the Tasman World, 1769-1840, Pickering \& Chatto, London.

Stevens, Michael J. 2011, “What's in a name?”: Murihiku, colonial knowledge-making, and "thin-culture", Journal of the Polynesian Society 120(4): 333-47.

Stevens, Michael J. 2015, 'A "useful” approach to Maori history', New Zealand Journal of History 49(1): 54-77.

Te Punga Somerville, Alice 2012, Once Were Pacific: Maori Connections to Oceania, University of Minnesota Press, Minneapolis.

Thomas, Nicholas 1991, Entangled Objects: Exchange, Material Culture and Colonialism in the Pacific, Harvard University Press, Cambridge, MA.

Tsing, Anna Lowenhaupt 2004, Friction: An Ethnography of Global Connection, Princeton University Press, Princeton.

Walter, Richard, Chris Jacomb and Sreymony Bowron-Muth 2010, 'Colonisation, mobility and exchange in New Zealand prehistory', Antiquity 84(324): 497-513. doi.org/10.1017/S0003598X00066734

Williams, Henry 1823, Journal, Alexander Turnbull Library, National Library of New Zealand, Wellington, Micro-MS 0209 
This text is taken from Indigenous Mobilities: Across and Beyond the Antipodes, edited by Rachel Standfield, published 2018 by ANU Press, The Australian National University, Canberra, Australia.

doi.org/10.22459/IM.06.2018.05 